\title{
Original article (short paper) \\ A survey of body practices and primary health care in a district of São Paulo, Brazil
}

\author{
Yara M. Carvalho \\ Edison de J. Manoel \\ University of São Paulo, São Paulo, SP, Brazil
}

\begin{abstract}
The present study surveyed the profile of people who did or did not take part in programs and activities in primary healthcare units in the Butantã district, the city of São Paulo, Brazil. The rationale for the study was the concept of body practice understood as a practice of health and care. A semi-structured questionnaire was applied to 1090 individuals mostly middle-aged housewives. Only $5.78 \%$ of respondents were enrolled in some program and activities, mainly walking and stretching. There was a consensus between participants and non-participants on the importance of initiatives geared to care for the body and attention to health. The difficulties for having access to programs and the lack of options in the health public service were pointed out as the main obstacles for a greater involvement by local population.
\end{abstract}

Keywords: body practices, primary health care, health promotion, physical activity programs

Resumo- - "Uma pesquisa de práticas corporais e cuidados primários de saúde em um bairro de São Paulo, Brasil." Partimos do conceito prática corporal compreendida como prática de saúde e cuidado para identificar o perfil das pessoas que participam ou não de programas e atividades em Unidades Básicas de Saúde (UBS) no distrito Butantã, município de São Paulo. Um questionário semi-estruturado foi aplicado junto a 1090 pessoas, a maioria donas de casa de meia idade. Apenas 5,78\% dos respondentes participavam de algum programa, principalmente de caminhadas e atividades de alongamento. Houve consenso entre participantes ou não no que se refere a importância de iniciativas voltadas para o cuidado do corpo e atenção à saúde, de modo geral. Entretanto, as dificuldades de acesso aos programas da UBS e a falta de opções no serviço público de saúde foram apontados como os principais impedimentos para um maior envolvimento da população local.

Palavras-chave: práticas corporais, atenção básica em saúde, promoção da saúde, programas de atividade física

Resumen - "Un estudio de las prácticas corporales y la atención primaria de la salud en un distrito de São Paulo, Brasil." Partimos desde el concepto de práctica corporal comprendida como práctica de salud y cuidado para identificar el perfil de las personas que participan o no de programas y actividades en Unidades Básicas de Salud (UBS) en el distrito Butantã, municipalidad de São Paulo. Un cuestionario semi-estructurado fue aplicado en 1090 personas, la mayoría amas de casa de mediana edad. Solo $5,78 \%$ de los respondientes participaban de algún programa, sobre todo de caminadas y actividades de estiramiento. Hubo consenso entre participantes o no sobre la importancia de las iniciativas para el cuidado del cuerpo y atención en salud, de modo general. Todavía, las dificultades de acceso a los programas de la UBS y la falta de opciones en el servicio público de salud fueron identificadas como los principales impedimentos para una mayor participación de la populación local.

Palabras claves: prácticas corporales, atención primaria en salud, promoción de La salud, programas de actividad física

\section{Introduction}

Physical activity has been the subject of recurring discussion in health related fields, especially when the focus is primary health care. In fact, physical activity is included in the health policies of different countries, and especially in those countries concerned about the increase of chronic degenerative diseases (Blair, 2009; Booth, Lees, Rector\& Thyfault, 2008; Daugbjerg et al., 2009; The Lancet NCD Action Group and the NCD Alliance, 2011; WHO, 2010). Within this context, the present paper assumes a different standpoint by taking the term body practices as a counterpoint to term physical activity. Body practices can be seen as expressive forms in which values about body, health and ultimately life area manifested (Carvalho, 2006). Body practices have been used in the Brazilian scientific literature since the beginning of the 2000's by researchers in human sciences (Lazzaroti Fi1ho, Silva, Antunes, Silva, \& Leite, 2010; Silva \& Damiani, 2005), here these practices are understood as "manifestations of body culture of a given group of individuals that entail the meanings that they attribute to them...(body practices) operate according to a logic of embracement in the sense of being attentive to the people...listening to their desires and needs.."(Carvalho, 2007). There is still a preference for the use of physical activity among many segments of the academic field without the awareness that each term refer to quite 
different and opposed paradigms regarding to human movement and health. The term physical activity is commonly used in Epidemiology studies in which physical activity is referred mainly to energy expenditure; hence any moderate to vigorous physical activity is considered to have health benefits. "Body practices" is a concept used in collective health, a branch from public health which is characterized by carrying out investigations and interventions from the human and social sciences standpoint. On one hand, body practices can be considered as health strategies. On another hand, physical activity is acknowledged as a protective factor against chronic degenerative diseases, specially hypertension, diabetes, obesity, among others (Carvalho, 2003). After a nationwide discussion a National Policy of Health Promotion (Política Nacional de Promoção da Saúde-PNPS) was issued by the Brazilian Ministry of Health in which the expression physical activity/body practices appeared linked to the discussion of health promotion (Brasil, Secretaria de Vigilância em Saúde, 2006).

In Brazil, the "Sistema Único de Saúde-SUS" (the National Public Health System) has as one of its responsibilities the organization of care practices for the body. Body here not in the sense of an object, but body as lived (cf. Arnold, 1979). In the primary health care that takes place in the "Unidades Básicas de Saúde-UBS" (Health Basic Unities), the body practices have a privileged position, which means that at this level of health attention the user of the system can participate in specific programs (Campos, Minayo, Akerman, Drummond Jr., \& Carvalho, 2013).

The development of programs designed to take care of the body entails different elements and behaviors in people's daily lives as well as the production, access, and exchange of knowledge and practices in the health fields regarding body practices. By changing the focus from disease to the dimension of health a major investigation was carried out with the purpose of assessing how body practices were implemented in the public health services from the meanings participants and non-participants attributed to them. In the last decade there has been a growing interest in body practices with a focus to the dimension of health by the population in the United States as is shown by a survey carried out by the National Institutes of Health from the US Department of Health and Human Services. In 2007, the percentage of U.S. adults who took part in body practices was 29.3 (Barnes, Bloom, $\&$ Nahim, 2008). Although the SUS has the responsibility to provide body practices, little is known on how many people is engaged in these practices. Borges et al. (2011) reports on the success of a body practice program specific to deal with back problems for users of a health basic unit. The program involved body practice integrated with knowledge on the properties of the body and the spine with 29 individuals (mostly women in their fifties and sixties) taking part in it. The individuals who took part in this program reported a decrease in back pains and also showed an improvement on indicators of quality of life. In another study Coelho et al. (2011) reports on the improvement of aspect of the quality of life for twenty five women, between 20 and 65 years of age, who engaged in a body practice program of yoga. The program was promoted by the city council; hence its results need to be taken with caution as far as the interest in this paper is to investigate body practice within the context of primary health care.

Most of studies on health promotion investigate the effect of particular interventions on specific groups, on the adherence of given age groups to physical activity programs and the levels of physical activity among the population. In spite of the importance and relevance of this research effort, it does not go beyond to unveil the extent in which there is a global prevalence of inactivity in the world population. Recently, a systematic review has shown the effectiveness over at least twelve months of intervention to promote physical activity based in primary care in Britain, Switzerland, Netherlands, North America and New Zealand (Orrow, Kinmonth, \& Sutton, 2012). In this scenario, it is most important to gather information about how the population reacts to the opportunities for body practices being given in the primary health care system. This is all the more relevant if one considers, as has been pointed out by Gallegos-Carrillo et al. (2014), that the majority of studies have focused on the population from high-income countries. In the Gallegos-Carrillo et al. study, an investigation is proposed with a population from middle-income country focusing on the effectiveness of the Mexican Social Security Institute Primary Health Care Physical Activity referral scheme. The authors described a proposition for a cluster randomized trial study designed to evaluate the effectiveness of an exercise referral scheme to increasing physical activity in hypertensive patients compared to a non-referral scheme. Their aim is to target a large population that uses the primary health care services. This large population is usually the ones with low income hence with lesser opportunities to benefit from physical activity promotion in the context of health promotion. Although, the literature presents useful guidelines for Latin American countries on how to facilitate physical activity by indicating how to translate research findings into practice (cf. Pratt et al., 2010), little is known about the large population who do get to the health care primary system in search for physical activity and other health care practices.

The present paper reports on one part of the investigation dedicated to assess the promotion of body practices in the primary health care. The purpose of the study reported here was to survey the profile of users of the SUS who did or did not participate in the body practices programs offered by the public health services in the city of Sao Paulo.

\section{Method}

\section{Participants}

The participants came from two Health Basic Unities (HBU), henceforth called HBU1 and HBU2, and one park, Park 1, in the Butantã district, West zone of the City of São Paulo. The district has an area of $1250 \mathrm{Km}^{2}$ square kilometers and a population of 54,196 inhabitants. The demographical 
density is of 4,336 inhabitants per $\mathrm{Km}^{2}$. The sample population came from the people attending these three places seeking advice and treatment for health reasons. The selection of these HBUs and the park was based on previous research (Martins et al., 2006; Warschauer et al., 2007) indicating that they were representative of the 14 HBUs under the jurisdiction of the Health Authority of the Butantã District. Another criterion for the selection was the receptivity toward the research proposal showed by health professional staff in these places and the existence of regular and permanent physical activity and body practices programs. The availability of these programs to the community thus offered a unique opportunity to investigate the motives of people who do or do not participate in such practices.

The two HBUs had 32,721 individuals registered as users of the service. The number of users in Park 1 could not be estimated because this community center received a lot of people who were not looking for health care. The sample size of the present study was 1090 users. There were 411 respondents from the HBU 1 that took part in the study, 407 respondents from the HBU2, and 272 from Park1. From this sampling 64 respondents participated in body practices programs offered by the service and 1026 respondents did not participate in any such programs. All participants were informed about the purpose of the survey and gave their written consent before taking part. This study was approved by the Ethics Research Committee of the Health Authority of the City of São Paulo (CAAE 0243.0.162.342-09).

\section{Procedure}

The investigation combined qualitative and quantitative procedures and a team composed of a researcher and graduate and undergraduate students, all specially trained for the task, carried it out. Data collection took seven weeks to be completed, with the research team working seven days a week. The population was surveyed on the premises of the HBUs and the park in two phases: In Phase 1 a questionnaire was applied to survey the socioeconomic profile of respondents who had joined the body practices programs and those who had not. The questions were: (a) age of the respondent; (b) sex; (c) marital status; (d) occupational status (employed, unemployed, retired); (e) individual and family wages; (e) whether the respondent is a user of the SUS; (f) whether the respondent has a private health insurance. In Phase 2 ninety two individuals were interviewed. They all had responded the questionnaire in Phase 1. The goal was to evaluate their opinions about the programs of body practices programs offered by the service. The interview had six open questions: (1) "Do you agree with the initiatives toward the body practices offered by the SUS?" This question was meant to verify whether the users acknowledge that the SUS offers programs with body practices and whether they agree with this initiative; (2) "Are you adept of these practices (a list of body practices was presented) offered by the SUS?" This question was meant to survey what body practices users would consider more interesting. (3) "Do you agree with the Asian oriented body practices offered by the SUS?" This question was intended to assess whether the users acknowledge the range of body practices that were originated in Asia, particularly China. (4) "Are you fond of some of these Asian oriented body practices (a list of these practices was presented) offered by the SUS?" With this question we wanted to survey which Asian oriented body practice the users would be most interested. (5) "Do you agree with the integrative medicine offered by the SUS?" (6) "Are you fond of some of these integrative medicines (a list of integrative medicines was presented) offered by the SUS?" The purpose of these last two questions was to investigate whether the users acknowledge the integrative medicines being offered by the SUS and whether they might show some preference for one of them.

The present paper dealt mostly with the data gathered in Phase 1. Wherever appropriate, some results of the interviews will be also presented to support some conclusions drawn from the quantitative data.

\section{Data collection and analysis}

The quantitative data from the questionnaires were processed using a statistical software package SPSS 19. To have a complete survey of the participants, descriptive reports were generated with relative and absolute frequencies and box plots. Because of the exploratory nature of the present investigation, descriptive statistics were calculated with means, standard deviation, and median where appropriate.

\section{Results}

The mean age of users who responded the questionnaires was 43 years $(\mathrm{SD}= \pm 16.99$ years, variance $=288.94$, ranging from 13-92 years). The majority was married (50.1\%). Additionally, $23.9 \%$ of respondents were single and $9.4 \%$ came from a stable couple union ${ }^{1}$. In regard to the question of monthly income, $8.25 \%$ of the individuals were not comfortable in declaring their wages. The mean monthly wage was $\mathrm{R} \$ 922.56$ (approximately US $\$ 452.00$ ). Sample stratification by quartiles found that less than $25 \%$ of respondents were without income. This might be due to the fact the majority of respondents were women who declared themselves housewives. An income of $\mathrm{R} \$ 1020.00$ (US\$500.00) corresponded to the third quartile which means that $75 \%$ of the respondents earned less than this.

Table 1 presents eight levels of schooling found in the sample. From the 1090 questionnaires only 13 (1.2\%) did not give reliable data to characterize level of schooling. The majority of respondents were literate with only $2.2 \%$ considered illiterate. Among the literate individuals $31 \%$ did not complete an elementary education and $30 \%$ had completed secondary education. Individuals with higher education and graduate education corresponded to $12 \%$ of the total sample.

${ }^{1}$ The Brazilian Civil Code acknowledges as official the union of couples who live together with the purpose of constituting a family. 
Table 1. Level of Schooling among the users of the SUS.

\begin{tabular}{|c|c|c|c|c|c|}
\hline & & Frequency & $\%$ & $\%$ valid & $\%$ cumulative \\
\hline \multirow[t]{9}{*}{ Valid Data } & Illiterate & 24 & 2.2 & 2.2 & 2.2 \\
\hline & Incomplete elementary education & 338 & 31.0 & 31.4 & 33.6 \\
\hline & Complete elementary education & 118 & 10.8 & 11.0 & 44.6 \\
\hline & Incomplete secondary school & 73 & 6.7 & 6.8 & 51.3 \\
\hline & Complete secondary school & 330 & 30.3 & 30.6 & 82.0 \\
\hline & Incomplete higher education & 44 & 4.0 & 4.1 & 86.1 \\
\hline & Complete higher education & 132 & 12.1 & 12.3 & 98.3 \\
\hline & Graduate education & 18 & 1.7 & 1.7 & 100 \\
\hline & Subtotal & 1077 & 98.8 & 100 & \\
\hline Missing Values & Subtotal & 13 & 1.2 & & \\
\hline General Total & & 1090 & 100 & & \\
\hline
\end{tabular}

As far as to health care services are concerned, $88.3 \%$ of respondents were users of the SUS and $27.4 \%$ had private health insurance. Almost every respondent (98.3\%) agreed with the initiatives toward the body practices in the SUS, although only $5.6 \%$ of respondents participated in the programs offering them. With regard to the Asian oriented body practices offered by the SUS, 1015 respondents said they agreed with the initiatives that yielded a valid percent of 94 . However, only 63 respondents answered that they were adpet of Asian oriented body practices which corresponded to a valid percent of 5.8. Similar results were obtained for the integrative medicines, with $94.6 \%$ in favor of them in the SUS, but with only $2 \%$ having participated in them. Hence, there is a clear pattern of responses from the users with most of them having no objection to body practices in general, and to the Asian oriented ones and integrative medicines in particular, but who nonetheless showed a very low participation in such practices.
The respondents mentioned eighteen body practices offered by the SUS that they part in the service (Table 2). However, the number of participants in each of them was very low. The activity with most participants was walking and stretching, with $3.1 \%$ of the total number of users taking part in these practices.

The concept of body practices stands out as a tool to operationalize a change from sickness to heath in the intervention programs. In this sense, one group of body practices of particular interest is the Asian oriented body practices and also the practices united under integrative medicine. These practices are oriented to Eastern philosophies in which the mind-body relation is not as dichotomous as they are in body practices oriented by Western philosophies and for this reason they are suitable to establish body practices as practices of health rather than management of sickness (cf. Carvalho, 2010). The effect of such practices is already acknowledged in the treatment of drug abuse and clinical psychology in general (cf. Hall et al., 2011; Price et al., 2012).

Table 2. Frequency of participation in programs with body practices offered by the SUS.

\begin{tabular}{|c|c|c|c|c|}
\hline & Frequency & $\%$ & $\%$ valid & $\%$ cumulative \\
\hline Valid Data & 1028 & 94.3 & 94.3 & 94.3 \\
\hline Stretching & 4 & .4 & .4 & 94.7 \\
\hline Walking & 34 & 3.1 & 3.1 & 97.8 \\
\hline Walking and Stretching & 3 & .3 & .3 & 98.1 \\
\hline Walking and Crochet & 1 & .1 & .1 & 98.2 \\
\hline Walking and Dance & 1 & .1 & .1 & 98.3 \\
\hline Walking and Gymnastics & 1 & .1 & .1 & 98.3 \\
\hline Chi Gong & 1 & .1 & .1 & 98.4 \\
\hline Physical training and football & 1 & .1 & .1 & 98.5 \\
\hline Circular Dance & 2 & .2 & .2 & 98.7 \\
\hline Scouting & 1 & .1 & .1 & 98.8 \\
\hline Sports $^{1}$ & 1 & .1 & .1 & 98.9 \\
\hline Exercise $^{2}$ & 1 & .1 & .1 & 99.0 \\
\hline Football & 1 & .1 & .1 & 99.1 \\
\hline Football and Gymnastics & 1 & .1 & .1 & 99.2 \\
\hline Gymnastics & 3 & .3 & .3 & 99.4 \\
\hline Acqua-gymnastics & & .1 & .1 & 99.5 \\
\hline Games & 1 & .1 & .1 & 99.6 \\
\hline Tai Chi & 4 & .4 & .4 & 100 \\
\hline Total & 1090 & 100 & 100 & \\
\hline
\end{tabular}

1. The term "sports" was mentioned by the users as synonymous of physical activity like walking, running, etc.

2. The term "exercise" was mentioned by the users as synonymous of physical fitness conditioning. 
Table 3. Frequency of participation in programs with Asian oriented body practices offered by the SUS.

\begin{tabular}{|c|c|c|c|c|c|}
\hline & & Frequency & $\%$ & $\%$ valid & $\%$ cumulative \\
\hline \multirow[t]{10}{*}{ Valid Data } & & 1029 & 94.4 & 94.4 & 94.4 \\
\hline & Chi Gong & 6 & .6 & .6 & 95.6 \\
\hline & Chi Kung & 1 & .1 & .1 & 95.0 \\
\hline & Chi Kung and Tai-Chi & 1 & .1 & .1 & 95.1 \\
\hline & Lian Gong & 3 & .3 & .3 & 95.4 \\
\hline & Lian Gong and Dao Yin & 1 & .1 & .1 & 95.5 \\
\hline & Tai Chi & 44 & 4.0 & 4.0 & 99.5 \\
\hline & Tai Chi and Lian Gong & 4 & .4 & .4 & 99.9 \\
\hline & Tai Chi and Chi Kung & 1 & .1 & .1 & 100.0 \\
\hline & Total & 1090 & 100 & 100 & \\
\hline
\end{tabular}

There is evidence that Asian oriented practices and others stemming out from them provides better relationship somato-emotional awareness, coping and emotional regulation (Wang et al., 2010).

Asian oriented body practices offered by the SUS were diverse, as shown in Table 3. Nevertheless, the number of participants in each practice was again very low, varying from one to four individuals. The practice with the most number of participants (4\%) was Tai Chi.

The number of participants in integrative medicines was lower than the number for the previously mentioned practices. Acupuncture had 13 participants, corresponding to $1.2 \%$ of the total number of respondents' users (Table 4).

The frequency of participation in the programs was similar in the two HBUs and but a little lower in the community center in the park in regard these two. The proportion of the respondents' users who participated in body practices in the HBU 1 was $34.4 \%$ while in the HBU2 it was $37.7 \%$. In Park $1,27.9 \%$ of the participants were engaged in some program of body practices.

The relationship between participation/non-participation was greater in the female users than in the male users (Table 5 ). The participation of women in at least one of the programs offered by the SUS varied between 80 and $90 \%$. This sociodemographic analysis indicates that middle-aged women with low level income and low le schooling predominate among those participants in the sample. Hence participation in body practices programs is concentrated in people without regular jobs other than homecare. With regard to marital status, there was a predominance of widows and widowers participating in the body practices. Among those who participated in these practices, the majority of the users had not completed an elementary education. Furthermore, among the respondents' users who participated in the programs the majority were regular users of the SUS.

The mean age of respondents' users who participated in the programs was slightly higher than those who had not participated. The family income for those who had participated was lower than those who had not. It is interesting to note that among the users who participated in the programs with body practices there were a slightly higher proportion of respondents' users who had private health insurance. This runs counter to the expectation that a higher proportion of users who participate in the programs would be those without private health insurance and thus dependent upon the SUS for health services, given that the programs are free of charge. It is noteworthy to point out that all participants of the integrative medicine programs were regular users of the SUS.

The interviews showed some interesting results. Almost every respondent (98.3\%) agreed with the initiatives toward the body practices in the SUS, although only $5.6 \%$ of respondents participated in the programs offering them. Nevertheless when asked, $85 \%$ of the respondents manifested their intention to participate in a new program. With regard to the Asian oriented bodily practices offered by the SUS, again the majority of respondents (94\%) agreed with their presence in the service, although only a small proportion of them $(5.8 \%)$ participated in the programs offering such practices. Similar results were obtained for the integrative medicines, with $94.6 \%$ in favor of them in the SUS, but with only $2 \%$ having participated in them. Hence, there is a clear pattern of responses from the users with most of them having no objection to body practices in general, and to the Asian oriented ones and integrative medicines in particular, but who nonetheless showed a very low participation in such practices.

Table 4. Frequency of participation in programs of integrative medicines offered by the SUS.

\begin{tabular}{|c|c|c|c|c|c|}
\hline & & Frequency & $\%$ & $\%$ valid & $\%$ cumulative \\
\hline \multirow[t]{5}{*}{ Valid Data } & & 1068 & 98.0 & 98.0 & 98.0 \\
\hline & Acupuncture & 13 & 1.2 & 1.2 & 99.2 \\
\hline & Acupuncture \& Homeopathy & 1 & .1 & .1 & 99.3 \\
\hline & Homeopathy & 8 & .7 & .7 & 100 \\
\hline & Total & 1090 & 100 & 100 & \\
\hline
\end{tabular}


Table 5. Socio-demographic profile of users who did or did not participate in the programs with body practices offered by the SUS.

\begin{tabular}{|c|c|c|c|c|c|c|}
\hline \multirow[b]{2}{*}{ PARTICIPATION } & \multicolumn{2}{|c|}{ Body Practices Programs } & \multicolumn{2}{|c|}{$\begin{array}{c}\text { Asian oriented Body Practices } \\
\text { Programs }\end{array}$} & \multicolumn{2}{|c|}{ Integrative Medicines } \\
\hline & Yes & No & Yes & No & Yes & No \\
\hline \multicolumn{7}{|l|}{ GENDER (\%) } \\
\hline Male & 18 & 23.2 & 9.5 & 23.9 & 9.1 & 23.2 \\
\hline Female & 82 & 76.8 & 90.5 & 76.1 & 90.9 & 76.8 \\
\hline \multicolumn{7}{|l|}{ MARITAL STATUS (\%) } \\
\hline Single & 13.8 & 25.2 & 9.7 & 25.3 & 31.8 & 24.3 \\
\hline Married & 41.4 & 50.6 & 48.4 & 50.4 & 50 & 50.2 \\
\hline Widowed & 29.3 & 6.8 & 30.6 & 6.5 & 13.6 & 7.9 \\
\hline Divorced & 6.9 & 4 & 6.5 & 4 & 4.5 & 4.1 \\
\hline Stable union & 3.4 & 10 & 1.6 & 10.1 & 0 & 9.8 \\
\hline Separated & 5.2 & 3.5 & 3.2 & 3.6 & 0 & 3.7 \\
\hline \multicolumn{7}{|l|}{ SUS’s USER (\%) } \\
\hline Yes & 98.4 & 1.6 & 98.4 & 1.6 & 100 & - \\
\hline No & 87.6 & 12.4 & 87.5 & 12.4 & 87.3 & 12 \\
\hline \multicolumn{7}{|l|}{ PRIVATE HEALTH INSURANCE (\%) } \\
\hline Yes & 21.3 & 78.7 & 87.5 & 12.5 & 27.3 & 72.7 \\
\hline No & 28.1 & 71.9 & 36.5 & 63.5 & 27.8 & 72.2 \\
\hline \multicolumn{7}{|l|}{ FAMILY INCOME } \\
\hline $\begin{array}{l}\text { Age } \\
\text { (mean years) }\end{array}$ & 58.4 & 42.6 & 62.9 & 42.2 & 50.4 & 43.3 \\
\hline $\begin{array}{l}\text { Individual Wages } \\
\text { ( } \mathrm{R} \$ \text {, median) }\end{array}$ & 690.1 & 936.2 & 510 & 1500.8 & 917.6 & 923.2 \\
\hline Family Wages (R\$, median) & 1840 & 2090 & 1977.7 & 2082.1 & 1789 & 2085.2 \\
\hline \multicolumn{7}{|l|}{ SCHOOLING (\%) } \\
\hline Illiterate & 6.6 & 2 & 4.8 & 2.1 & 0 & 2.3 \\
\hline Incomplete Elementary Education & 45.9 & 30.6 & 49.2 & 30.4 & 31.8 & 31.4 \\
\hline $\begin{array}{l}\text { Complete Elementary Education } \\
\text { Complete Secondary Education }\end{array}$ & 18 & 10.6 & 20.6 & 10.2 & 13.6 & 11 \\
\hline Incomplete Secondary Education & 3.3 & 6.9 & 4.8 & 6.8 & 4.5 & 6.7 \\
\hline Complete Secondary Education & 18 & 31.3 & 11.1 & 31.8 & 31.8 & 30.6 \\
\hline Incomplete Higher Education & 1.6 & 4.2 & 1.6 & 4.3 & 4.5 & 4.1 \\
\hline Complete Higher Education & 6.6 & 12.6 & 7.9 & 12.6 & 13.6 & 12.3 \\
\hline Complete Graduate Education & 0 & 1.8 & 0 & 1.8 & 0 & 1.7 \\
\hline
\end{tabular}

One interesting result stemming from the interviews was with regard to the self-reported use of medicines/drugs. Of those users who participated in the programs, $42 \%$ believed that the practices reduced their use of drugs and medicines. However, $53 \%$ of the participants did not believe that the practices had any effect on such use. There was also a report of a significant improvement in social relationships, within the family $(62 \%$ of the participants) and outside ( $73 \%$ of the participants). Social support for physical activity and exercise is known to increase adherence to these practices (Kotecki, 2011). The participants are referring to a different relationship: body practices having a positive effect on the quality of their social relationships. This is an interesting relationship and needs to be explored further in new studies. There was also an association with psychological states related to mood and stress. For example, $77 \%$ of the participants reported changes in their mood while $73 \%$ mentioned positive changes in stress. Overall, $86 \%$ of participants reported improvements in quality of life. The responses are in agreement with overall thinking that exercise has positive effects on the psychological well being of individuals and their improved perception of quality of life (Weir, 2011). A word of caution needs to be taken though as the exercise effect is not as sound as one would expect from more rigorous research investigations (Scully et al., 1998) though recently the increase in the number of well controlled studies have provided more sound evidence to suggest the importance physical activity has for psychological states and perception of life quality (Ströhle, 2009). There is need for studies combining self reports with a more direct measurement of mood states. 


\section{Strengths and limitations}

The study reported here had as its strength the size of the sample in regard to the community attending the primary health care of highly populated area of the city of São Paulo with just above 54 thousand inhabitants. The study had a sample of 1090 participants from the universe of 32 thousand users of the two HBUs and the community center in the park. Previous research (Martins et al. 2006) indicated that the sample was representative of the population using the services of the 14 HBUs in the area of the Health Authority of the District of Butantã. This is one of few studies that paid attention to the participation of users of the health services in regard to body practices.

The study reported here was a survey and as such it needs to done on a relatively large and representative sample that was accomplished. Nevertheless, survey studies will have its shortcomings if one tries to go beyond the profile it provides and attempt to seek for causal relationships. Obviously the answers given by the respondents led us to elaborate on what could be the factors affecting behavior and perceptions toward the service. These warrant further investigations going back to the same places and focusing on a more reduced sample to pinpoint factors behind behaviors and perceptions. As far as the survey study is concerned two questions need to be modified in further investigation. One is the question about how many people in the family contribute to the income. The question did not specify whether those who contribute were also taking part in the programs. Hence, in the questionnaires some interviewers did specify this to the respondents, others not. This indicated that the question should be reviewed. The other question is about the age of respondents and their schooling levels. The answers to these questions were confused with some respondents giving only their schooling level. This contributed to elevate the number of missing values. The volume of questionnaires to be handled was great by each interviewer, and the conditions to administer them were not always the better ones, as there was not a specific place in the premises of the HBUs and the park to conduct the procedures. These shortcommings can be minimized with better training for interviewers, i.e. training focusing on the difficulties now learned to be typical in the environment of HBUs. Another action entails the adaptation of the questionnaires on the basis of the information gathered about the socioeconomic profile of the population that attend the primary health care services.

One variable that needs further consideration particularly in regard to the perception of the services is the category "participant" and "non participant." One striking result was the high level agreement with the body practices being offered by the services while the participants, individuals who actually took part in the referral body practices, were very few. Further surveys need to be carried out to pin point what makes one agrees with the practices being offered but do not feel compel to adhere to them. Nevertheless, there is one hypothesis that might explain this as will be presented next.

\section{Conclusion}

Despite the huge number of people using the public health services in a district of the city of São Paulo, participation in programs with body practices was still very low. Nevertheless the majority of the people surveyed acknowledged the importance of these programs and agreed with their offering. Taking this result with the data disclosing the predominance of middle-aged women who do note regular jobs among the participants in the body practice programs, one possible hypothesis is that the problem precluding insertion in the programs is their availability by the services. Body practice programs are offered within the openning hours which is from 7 am to 5 pm, Monday to Friday. It is unlikley that individuals with regular jobs will be able to attend and adhere to body practice programs. What might explain this operational problem is concerned with the perception about the body practices programs among health professionals in the service, particularly the local managers. Body practices programs are not highly valued by many health professionals. This will create logistic problems in terms of restricted spaces in the premises to carry out the practices and also of time for the health professionals willing to conduct the body practices programs but who are always overwhemeld with other duties.

Body practice programs need to be analysed in conceptual terms. In the present paper has assumed a standpoint according to with the body practices more adequate to primary health care are those in which the body is not taken as an object, but as lived. One perspective differs from the other in terms of the focus, the former deals with sickness, the latter with health, hence with more integrated or holistic proposition (what makes the analysis and impact of the Asian oriented practices worthwhile pursuing). In this sense some body practices programs such as "Walking and Stretching" treats body as an object as they are heavily oriented to specific groups defined by sickness such as diabetes, hypertension and coronary diseases. The importance of these programs is not denied, but their focus make them more restrictive to the participation of others users. The fact that body practice programs such as Walking and Strechting predominate in the initiatives the service promote might contribute to a low involvement in such practices.

Overall, the socio-demographic analysis carried out indicates that individuals who got to the primary health care services have low income, low levels of schooling. They all agree on the importance of body practices programs and even manifested desire to take part in such programs, but they complained about the lack of opportunities to do so. This is well in accord with the literature that indicate as the main factor precluding participation in body practices is low income, low levels of schooling and lack of time (Martins et al., 2006; Warschauer et al., 2007).

Public health policies (e.g., National Policy of Health Promotion, National Policy on Integrative and Complementary Practices, Academy of Health, Health in School) have called attention to the role of body practices for health promotion and as it was mentioned before the primary health care seems to be the best context for the effectiveness of initiatives promoting people's physical activity (Orrow et al., 2012) . 
However, what is shown by the present research is that the conditions for the programs are inadequate: the service opening hours are insufficient and the focus is on the sickness process despite the policies privileging health promotion.

Future research should consider the user who pays attention to the information regarding to the programs offered being able to distinguish between physical activities programs and body practices programs, hence programs that focus on the risk and sickness (through energy/caloric expenditure, for example) from programs concerned with health promotion (that considers meanings attributed to body practices). Research should also be conducted on the environmental atmosphere or motivational environment in the HBUs which is very important to create a welcoming space for dealing with health rather than sickness. This will range from considering the architecture of the premises (cf. Hollands et al., 2013) to the perception of health workers have on a number of issues particularly those related to their understanding on a paradigm focusing on health rather than sickness and on the concept of body practice from a phenomenological standpoint.

\section{References}

Academia da Saúde. Avaliable at http://dab.saude.gov.br/portaldab/ ape_academia_saude.php.

Arnold, P.J. (1979). Meaning in movement, sport and physical education. London: Methuen.

Barnes, P.M., Bloom, B. \& Nahin, R.L. (2008). Complementary and alternative medicine use among adults and children: United States, 2007. National Health Statistics Report, \#12, December 10.

Blair S. (2009). Physical inactivity: the biggest public health problem of the $21^{\text {st }}$ century. British Journal Sports Medicine, 43(1), 1-2.

Booth, F.W., Laye, M.J., Lees, S.J., Rector, R.S., \& Thyfault, J.P. (2008). Reduced physical activity and risk of chronic disease: the biology behind the consequences. European Journal of Applied of Physiology , 102, 381-390.

Borges, R.G., Vieira, A., Noll, Bartz, P.T., \& Candotti, C.T. (2011). Efeitos da participação em um Grupo de Coluno sobre as dores musculoesqueléticas, qualidade de vida e funcionalidade dos usuários de uma Unidade Básica de Saúde de Porto Alegre - Brasil. Motriz, 17, 719-727.

Brasil, Secretaria de Atenção à Saúde. Departamento de Atenção Básica (2006). Política Nacional de Práticas Integrativas e Complementares no SUS. Avaliable at http://dab.saude.gov.br/portaldab/ biblioteca.php?conteudo=publicacoes/pnpic.

Brasil, Secretaria de Vigilância em Saúde (2006). Secretaria de Atenção Básica à Saúde: Política Nacional de Promoção da Saúde. Available at http://portal.saude.gov.br/portal/arquivos/pdf/pactovolume7.pdf.

Brasil, Ministério da Saúde. Secretaria de Atenção à Saúde. Departamento de Atenção Básica (2009). Saúde na escola. Brasília.

Campos, G.W.S., Minayo, M.C.S., Akerman, M., Drumond Jr., M., \& Carvalho, Y.M. (2013). Tratado de Saúde Coletiva. 2nd. expanded edition. São Paulo: Hucitec.

Carvalho, Y.M. (2003). Educação Física e Saúde Coletiva: uma introdução. In M.T. Luz (Ed.). Novos saberes e práticas em saúde coletiva: estudo sobre racionalidades médicas e atividades corporais (pp. 19-34). São Paulo: Hucitec.

Carvalho, Y.M. (2006). Promoção da saúde, práticas corporais e atenção básica. Revista Brasileira Saúde da Família, 33-45.
Carvalho, Y. M. (2007). Práticas corporais e comunidade: Um projeto de educação física no Centro de Saúde Escola Samuel B. Pessoa (Universidade de São Paulo). In A. B. Fraga \& F. Wachs (Eds.). Educação física e saúde coletiva: Politicas de formação e perspectivas de intervenção. Porto Alegre: Editora da UFRGS.

Carvalho, Y.M. (2010). As práticas corporais como práticas de saúde e de cuidado no contexto da promoção da saúde. Tese de Livre Docência. São Paulo: Faculdade de Saúde Pública da Universidade de São Paulo.

Coelho, C.M., Lessa, T. T., Carvalho, R.M., Coelho, L.A., Scari, R.S., Fernandes, N.S., \& Novo Júnior, J.M. (2011). Qualidade de vida em mulheres praticantes de Hatha Ioga. Motriz, 17, 33-38.

Daugbjerg, S.B., Kahlmeier, S., Racioppi, F., Martin-Diener, E., Martin, B., Oja, P., \& Bull, F. (2009). Promotion of physical activity in the european region: content analysis of 27 national policy documents. Journal of Physical Activity and Health, 6,805-817.

Gallegos-Carrillo, K., García-Pena, C., Salmerón, J., Salgado-de-Snyder, V.N., Vázquez-Cabrer, G., \& Lobelo, F. (2014). Exercise -referral scheme to promote physical activity among hypertensive patients: Design of a cluster randomized trial in the primary health care units of Mexico's Social Security System. BMC Public Health, 14, 706 (10 July).

Hall, G.C., Hong, J. J., Zane, N.W.S., \& Meyer, O.L. (2011). Culturally competent treatments for Asian Americans: The relevance of mindfulness and acceptance-based psychotherapies. Clinical Psychology: Science and Practice, 18, 215-231.

Hollands, G., Shemilt, I., Marteau, T.M., Jebb, S.A., Kelly, M.P., Nakamura, R., ... Ogilvie, D. (2013). Altering micro-environments to change population health behavior: towards an evidence base for choice architecture interventions. BMC Public Health, 13,1218.

Kotecki, J.E. (2011). Physical activity \& health: An interactive approach. Sudbury, MA: Jones \& Bartlett Learning.

Lazzaroti, Filho, A., Silva, A.M., Antunes, P.C., Silva, A.P.S., \& Leite, J.O. (2010). O termo práticas corporais na literatura científica brasileira e sua repercussão no campo da Educação Física. Movimento, 16, 11-29.

Martins, C.L., Ferdinando, D. Freitas, F.F., Warschauer, M., Diniz, S.O., Pinto, T.R.S., \& Carvalho, Y.M. (2006). Avaliação das práticas corporais promovidas em Unidades Básicas de Saúde da região do Butantã. In Proceedings of the XI Congresso Mundial de Saúde Pública / VIII Congresso Brasileiro de Saúde Coletiva: 21-25 Ago 2006; Rio de Janeiro Edited by ABRASCO, Rio de Janeiro.

Orrow, G., Kinmonth, A.L., \& Sutton, S. (2012). Effectiveness of physical activity promotion based in primary care: systematic review and meta-analysis of randomised controlled trials. British Medical Journal, 344:e1389.

Pratt, M., Brownson, R.C., Ramos, L. R., Malta, D.C., Hallal, P.C., Reis, R.S., ... Simões, E.J. (2010). Project GUIA: a model for understanding and promoting physical activity in Brazil and Latin America. Journal Physical Activity and Health, suppl 2, S131-S134.

Price, C.J., Wells, E.A., Donovan, D.M., \& Rue, T. (2012). Mindful awareness in Body-oriented therapy as an adjunct to women's substance use disorder treatment: A pilot feasibility study. Journal of Substance Abuse Treatment, 43, 94-107.

Scully, D., Kremer, J., Meade, M.M., Graham, R., \& Dudgeon, K. (1998). Physical exercise and psychological well being: a critical review. British Journl Sports Medicine, 32, 111-120.

Silva, A.M., \& Damiani, I.R. (Orgs.) (2005). Práticas corporais: Experiências em educação física para uma formação humana. Florianópolis: Nauemblu Ciência \& Arte.

Ströhle, A. (2009). Physical activity, exercise, depression and anxiety disorders. Journal Neural Transmission, 116, 777-784. 
The Lancet NCD Action Group and the NCD Alliance (2011). Priority actions for the non-communicable disease crisis. The Lancet, 377 , 1438-1447.

Wang, C., Bannuru, R., Ramel, J., Kupelnick, B., Scott, T., \& Schmid, CH. (2010). Tai Chi on psychological well-being: systematic review and meta-analysis. BMC Complementary and Alternative Medicine, 10, 1-16.

Warschauer, M., Carvalho, Y.M., Martins, C.L., \& Freitas, F.F. (2007). As escolhas das práticas corporais e dos profissionais que as conduzem nas Unidades Básicas de Saúde do Distrito Butantã-SP. In Proceedings of the XV Congresso Brasileiro de Ciências do Esporte e II Congresso Internacional de Ciências do Esporte, 16-21 Set 2007; Recife. Edited by Colégio Brasileiro de Ciências do Esporte. Recife: CBCE/Edupe.

Weir, K. (2011). The exercise effect. Monitor on Psychology/APA, 42, 48. World Health Organization (2010). Global recommendations on physical activity for health. Geneva.

\section{Authors' note}

Yara M. Carvalho, associate professor, and Edison de J. Manoel, full professor, are affiliated with the School of Physical Education and Sport, University of São Paulo, São Paulo, Brazil.

\section{Acknowledgements}

The research was funded by FAPESP, Grant "Research on Public Policies for the SUS”, Process No. 06/61320-9.

\section{Corresponding author}

Edison de J. Manoel, Full Professor,
Av. Prof. Melo Morais, 65, Butantã, São Paulo, SP, 05508-030 Brasil E-mail: ejmanoel@usp.br

Manuscript received on July 22, 2014

Manuscript accepted on January 24, 2015

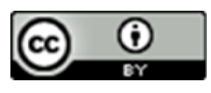

Motriz. The Journal of Physical Education. UNESP. Rio Claro, SP, Brazil - eISSN: 1980-6574 - under a license Creative Commons - Version 3.0 